\title{
Halomonas zhanjiangensis sp. nov., a halophilic bacterium isolated from a sea urchin
}

\author{
Correspondence \\ Wen-Jun Li \\ wjli@ynu.edu.cn \\ Yi-Guang Chen \\ mchenjsu@yahoo.com.cn
}

\author{
Yi-Guang Chen, ${ }^{1,2}$ Yu-Oin Zhang, ${ }^{2,3}$ Heng-Yu Huang, ${ }^{1}$ \\ Hans-Peter Klenk, ${ }^{4}$ Shu-Kun Tang, ${ }^{2}$ Ke Huang, ${ }^{1}$ Qi-Hui Chen, ${ }^{1}$ \\ Xiao-Long Cui ${ }^{2}$ and Wen-Jun Li ${ }^{2,5}$
}
${ }^{1}$ College of Biology and Environmental Sciences, Jishou University, Jishou 416000, PR China
${ }^{2}$ The Key Laboratory for Microbial Resources of the Ministry of Education, PR China, and Laboratory for Conservation and Utilization of Bio-Resources, Yunnan Institute of Microbiology, Yunnan University, Kunming 650091, PR China
${ }^{3}$ Institute of Medicinal Biotechnology, Chinese Academy of Medical Sciences \& Peking Union Medical College, Beijing 100050, PR China
${ }^{4}$ Deutsche Sammlung von Mikroorganismen und Zellkulturen, D-38124 Braunschweig, Germany
${ }^{5}$ Guangdong Key Laboratory of Marine Materia Medica, South China Sea Institute of Oceanology, Chinese Academy of Sciences, Guangzhou 510301, PR China

\begin{abstract}
A novel Gram-negative, slightly halophilic, catalase-positive, oxidase-negative, obligately aerobic, non-sporulating rod-shaped bacterium, designated strain $J S M 078169^{\top}$, was isolated from a sea urchin (Hemicentrotus pulcherrimus) collected from the South China Sea. Growth occurred with $1-20 \%(\mathrm{w} / \mathrm{v})$ total salts (optimum, $3-5 \%$ ), at $\mathrm{pH} 6.0-10.5$ (optimum, $\mathrm{pH} 7.5$ ) and at $4-40{ }^{\circ} \mathrm{C}$ (optimum, $25-30{ }^{\circ} \mathrm{C}$ ). The major cellular fatty acids were $\mathrm{C}_{18: 1} \omega 7 c, \mathrm{C}_{16: 0}$ and $\mathrm{C}_{12: 0} 3-\mathrm{OH}$. The predominant respiratory quinone was $Q-9$ and the genomic DNA G+C content was 55.8 mol\%. Phylogenetic analysis based on 16S rRNA gene sequences indicated that strain JSM $078169^{\top}$ should be assigned to the genus Halomonas. The sequence similarities between the isolate and the type strains of members of the genus Halomonas were in the range 92.4-97.0\%. The combination of phylogenetic analysis, DNA-DNA relatedness, phenotypic characteristics and chemotaxonomic data supported the view that strain JSM $078169^{\top}$ represents a novel species of the genus Halomonas, for which the name Halomonas zhanjiangensis sp. nov. is proposed, with JSM $078169^{\top}\left(=\right.$ CCTCC AB $208031^{\top}=$ DSM $21076^{\top}=$ KCTC $\left.22279^{\top}\right)$ as the type strain.
\end{abstract}

The genus Halomonas, belonging to the family Halomonadaceae (Franzmann et al., 1988; Dobson \& Franzmann, 1996; Ntougias et al., 2007; Ben Ali Gam et al., 2007), was first proposed by Vreeland et al. (1980) with the description of Halomonas elongata. In total, 58 species of the genus Halomonas have been described at the time of writing, including the recently described Halomonas korlensis (Li et al., 2008), Halomonas salifodinae (Wang et al., 2008) and Halomonas daqingensis (Wu et al., 2008). The members of this genus comprise halophilic/ halotolerant, chemo-organotrophic, Gram-negative rods and are widely distributed in saline habitats (Vreeland et al., 1980; Dobson \& Franzmann 1996; Mata et al., 2002; Romanenko et al., 2002; Arahal et al., 2007; Xu et al., 2007). Halomonas halocynthiae (Romanenko et al., 2002) was the first described Halomonas species isolated from

The GenBank/EMBL/DDBJ accession number for the 16S rRNA gene sequence of strain JSM $078169^{\top}$ is FJ429198. marine invertebrates. During the investigation of the diversity of the microbial population of invertebrates inhabiting the South China Sea (Chen et al., 2009a, b; Xiao et al., 2009), a novel Halomonas-like strain, designated JSM $078169^{\mathrm{T}}$, was isolated from a sea urchin (Hemicentrotus pulcherrimus) collected from a tidal flat of Naozhou Island, near a southern Chinese city, Zhanjiang. Based on the results of a polyphasic taxonomic study, this strain is considered to represent a novel species of the genus Halomonas.

Strain JSM $078169^{\mathrm{T}}$ was isolated from homogenates of a sea urchin (Hemicentrotus pulcherrimus) by plating $1: 10$ serial dilutions of the sample on marine agar 2216 (MA; Difco) cultivated at $28{ }^{\circ} \mathrm{C}$ for 1 week. After primary isolation and purification, the isolate was preserved both on MA slants at $4{ }^{\circ} \mathrm{C}$ and in marine broth 2216 (MB; Difco) supplemented with $20 \%(\mathrm{v} / \mathrm{v})$ glycerol at $-80{ }^{\circ} \mathrm{C}$. Unless otherwise indicated, morphological and physiological studies were performed with cells grown on MA at 
pH 7.5 and $28{ }^{\circ} \mathrm{C}$. Four reference strains, Halomonas variabilis DSM $3051^{\mathrm{T}}$, Halomonas boliviensis DSM $15516^{\mathrm{T}}$, Halomonas neptunia DSM $15720^{\mathrm{T}}$ and Halomonas sulfidaeris DSM $15722^{\mathrm{T}}$ were obtained from the DSMZ (Deutsche Sammlung von Mikroorganismen und Zellkulturen, Germany). Cell morphology was examined by using light microscopy (model $\mathrm{BH} 2$; Olympus). Gram staining was carried out by using the standard Gram reaction combined with the $\mathrm{KOH}$ lysis test method (Gregersen, 1978). Flagella were stained according to the method of Leifson (Smibert \& Krieg, 1994). Accumulation of poly- $\beta$-hydroxybutyrate was determined by using the Sudan Black staining method (Smibert \& Krieg, 1994) under a light microscope. Growth was tested at various temperatures $\left(0,4{ }^{\circ} \mathrm{C}\right.$ and $5-45{ }^{\circ} \mathrm{C}$, in increments of $\left.5{ }^{\circ} \mathrm{C}\right)$, $\mathrm{pH}$ (5.0-11.0, in increments of 0.5) and total-salt contents $(0,0.1$ and $0.5 \%, \mathrm{w} / \mathrm{v}$, and $1-20 \%, \mathrm{w} / \mathrm{v}$, at increments of $1 \%$ ) on MA and in $\mathrm{MB}$, prepared according to the formula of Atlas (1993). Growth was also tested with $\mathrm{NaCl}$ as the sole salt. Methyl red and Voges-Proskauer tests, $\mathrm{H}_{2} \mathrm{~S}$ production from L-cysteine, hydrolysis of aesculin, indole production, nitrate and nitrite reduction, phenylalanine deaminase and lysine and ornithine decarboxylases were tested as recommended by Smibert \& Krieg (1994).
Hydrolysis of casein, cellulose, DNA, gelatin, starch, Tweens 20, 40, 60 and 80 and urea were determined as described by Cowan \& Steel (1965). Motility, growth under anaerobic conditions, antibiotic-susceptibility tests, and catalase and oxidase activities were determined as described previously (Chen et al., 2007). Other enzymic activities were tested by using the API ZYM system (bioMérieux) according to the manufacturer's instructions except that the suspension medium was supplemented with $4 \%(\mathrm{w} / \mathrm{v})$ $\mathrm{NaCl}$. Acid production from carbohydrates and utilization of substrates as sole carbon or nitrogen sources and other phenotypic characteristics were determined as recommended by Ventosa et al. (1982) and Mata et al. (2002).

Strain JSM $078169^{\mathrm{T}}$ was able to grow with $1-20 \%(\mathrm{w} / \mathrm{v})$ total salts (optimum, 3-5\%) and at $\mathrm{pH} 6.0-10.5$ (optimum, $\mathrm{pH} 7.5$ ) and $4-40{ }^{\circ} \mathrm{C}$ (optimum, $25-30{ }^{\circ} \mathrm{C}$ ). Colonies were yellow-pigmented, flat and non-translucent with glistening surfaces and circular/slightly irregular margins, $2-3 \mathrm{~mm}$ in diameter after incubation for 35 days at $28{ }^{\circ} \mathrm{C}$ on MA. Cells were Gram-negative, nonsporulating, catalase-positive, oxidase-negative, motile, aerobic rods. The results of other phenotypic tests are summarized in the species description and in Table 1.

Table 1. Characteristics that distinguish strain JSM $078169^{\top}$ from phylogenetically related Halomonas species

Strains: 1, JSM $078169^{\mathrm{T}}$ (H. zhanjiangensis sp. nov.; data from this study); 2, H. variabilis DSM $3051^{\mathrm{T}}$ (Fendrich, 1988; Mata et al., 2002); 3, H. boliviensis $\mathrm{LC1}^{\mathrm{T}}$ (Quillaguamán et al., 2004); 4, H. neptunia Eplume1 ${ }^{\mathrm{T}}$ (Kaye et al., 2004); 5, H. sulfidaeris Esulfide1 ${ }^{\mathrm{T}}$ (Kaye et al., 2004). +, Positive; - , negative; ND, no data available.

\begin{tabular}{|c|c|c|c|c|c|}
\hline Characteristic & 1 & 2 & 3 & 4 & 5 \\
\hline Oxidase & - & + & ND & + & + \\
\hline pH range (optimum) & $6-10.5(7.5)$ & 6-9 (ND) & $6-11(7.5)$ & $5-12(7-8)$ & $5-10(7-8)$ \\
\hline $\begin{array}{l}\text { Salt range (optimum) } \\
(\%, w / v)\end{array}$ & $1-20(3-5)$ & $1-25(10)$ & $0-25(5)$ & $0.5-27(2-3)$ & $0.5-24(2-3)$ \\
\hline Nitrate reduction & + & - & + & + & + \\
\hline Respiration on nitrate & - & - & ND & + & + \\
\hline Facultative anaerobe & - & - & - & + & + \\
\hline $\mathrm{H}_{2} \mathrm{~S}$ production & - & + & - & - & - \\
\hline \multicolumn{6}{|l|}{ Acid production from: } \\
\hline D-Fructose & + & - & $\mathrm{ND}$ & - & - \\
\hline \multicolumn{6}{|l|}{ Utilization of: } \\
\hline Citrate & + & + & - & + & - \\
\hline D-Glucose & + & + & + & + & - \\
\hline Maltose & + & + & + & + & - \\
\hline D-Mannose & - & + & + & + & - \\
\hline L-Serine & + & + & $\mathrm{ND}$ & - & - \\
\hline $\begin{array}{l}\text { DNA G }+C \text { content } \\
(\mathrm{mol} \%)\end{array}$ & 55.8 & 61 & 51.4 & 57.3 & 56.0 \\
\hline
\end{tabular}


Genomic DNA was isolated according to Hopwood et al. (1985) and the DNA G + C content was determined using the HPLC method (Mesbah et al., 1989). The 16S rRNA gene was amplified and sequenced as described by Cui et al. (2001). The resulting 16S rRNA gene sequence was compared with sequences obtained from public databases (GenBank/EMBL/DDBJ) to find the most closely related species. Pairwise sequence similarities were calculated using a global alignment algorithm, implemented at the EzTaxon server (Chun et al., 2007). Phylogenetic analysis was performed by using the software package MEGA version 4.1 (Tamura et al., 2007) after multiple alignment of sequence data by using CLUSTAL_X (Thompson et al., 1997). Distances were calculated using distance options according to Kimura's two-parameter model (Kimura, 1980) and clustering was performed with the neighbour-joining method (Saitou \& Nei, 1987). Maximum-parsimony (Kluge \& Farris, 1969) and minimum-evolution (Felsenstein, 1997) trees (not shown) were generated by means of methods contained within the software package
MEGA version 4.1 (Tamura et al., 2007). Bootstrap analysis was used to evaluate the tree topology of the neighbourjoining data by means of 1000 resamplings (Felsenstein, 1985). DNA-DNA hybridization was carried out by using photobiotin-labelled probes in microplate wells as described by Ezaki et al. (1989).

The DNA G + C content of strain JSM $078169^{\mathrm{T}}$ was $55.8 \mathrm{~mol} \%$. An almost-complete $16 \mathrm{~S}$ rRNA gene sequence (1446 bp) was determined. Phylogenetic analysis based on $16 \mathrm{~S}$ rRNA gene sequences revealed that strain JSM $078169^{\mathrm{T}}$ belonged to the genus Halomonas, being related most closely to the type strains of $H$. variabilis (sequence similarity $97.0 \%), H$. boliviensis (96.9\%), H. neptunia $(96.7 \%)$ and $H$. sulfidaeris $(96.5 \%)$. These five strains constituted an independent subcluster in the phylogenetic tree, in which strain JSM $078169^{\mathrm{T}}$ occupied a distinct lineage branching at the periphery of the subcluster (Fig. 1). The sequence similarities between the isolate and the type strains of the other recognized Halomonas species were in

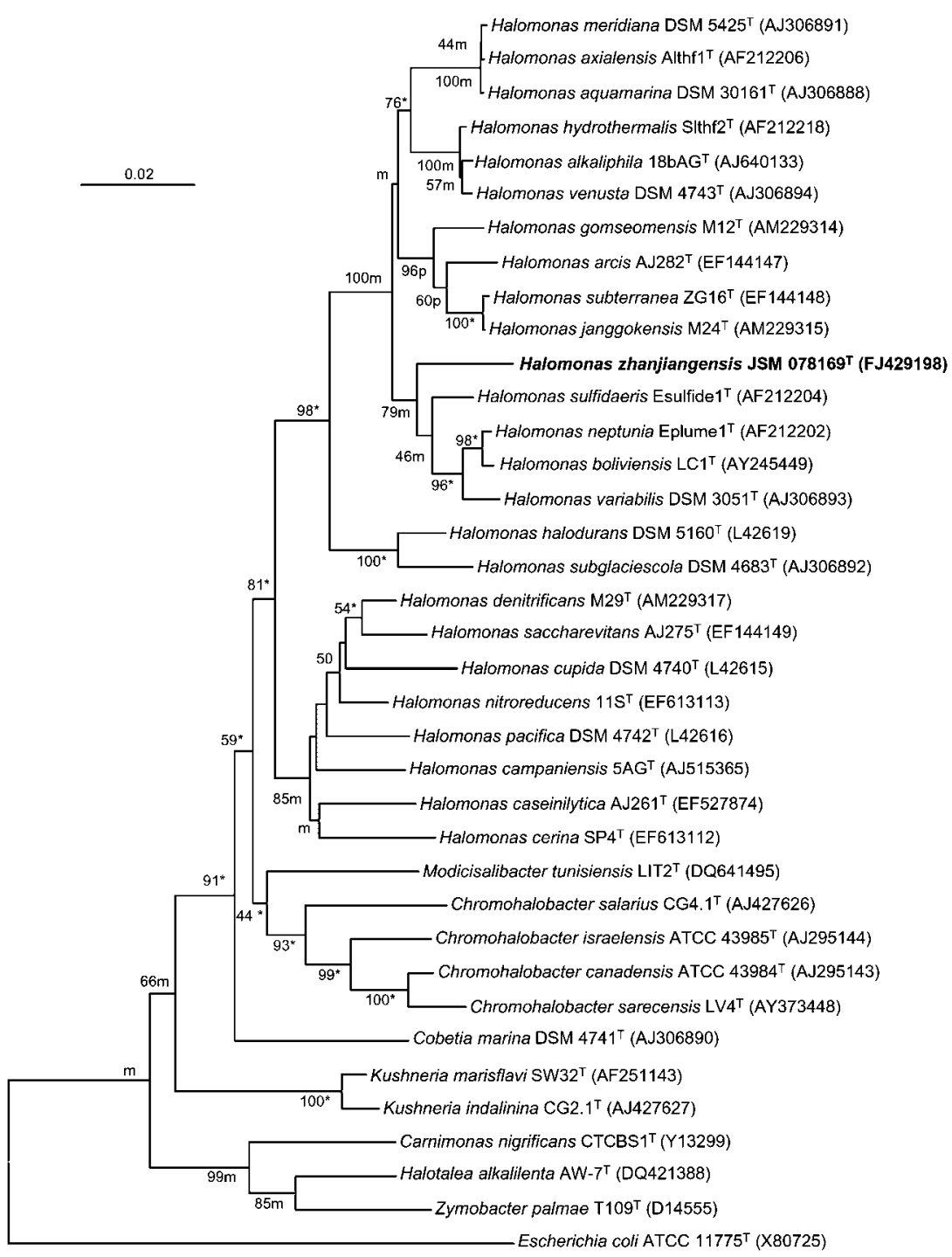

Fig. 1. Phylogenetic tree based on $16 \mathrm{~S}$ rRNA gene sequence analysis and constructed using the neighbour-joining method showing the phylogenetic positions of strain JSM $078169^{\top}$ and other related taxa. ' $m$ ' or ' $p$ ' indicate branches that were also found with the minimum-evolution (Felsenstein, 1997) or maximum-parsimony (Kluge \& Farris, 1969) algorithms, respectively; asterisks indicate branches that were recovered with all three methods. Numbers at nodes are bootstrap percentages $(>40 \%)$ based on a neighbourjoining analysis of 1000 resampled datasets. Bar, 2 substitutions per 100 nucleotides. 
the range 92.4-97.0\%. To establish the precise taxonomic position of strain JSM $078169^{\mathrm{T}}$, DNA-DNA hybridizations were performed between the novel isolate and the type strains of $H$. variabilis, $H$. boliviensis, $H$. neptunia and $H$. sulfidaeris, and the levels of DNA-DNA relatedness between them were 19.5, 15.4, 13.6 and $18.6 \%$, respectively. These values were far below the threshold value of $70 \%$ recommended by Wayne et al. (1987) for assignment of strains to the same species. Based on the results of the phylogenetic analysis and DNA-DNA hybridization, it was evident that strain JSM $078169^{\mathrm{T}}$ represents a previously unknown species of the genus Halomonas (Wayne et al., 1987; Stackebrandt \& Goebel 1994).

Isoprenoid quinones were analysed by HPLC as described by Groth et al. (1996). Fatty acids were determined for the novel isolate, as well as for the four reference strains, $H$. variabilis DSM $3051^{\mathrm{T}}$, Halomonas b. DSM $15516^{\mathrm{T}}, H$. neptunia DSM $15720^{\mathrm{T}}$ and H. sulfidaeris DSM $15722^{\mathrm{T}}$, as described by Sasser (1990) using the Microbial Identification System (MIDI; Microbial ID) with cells grown in $\mathrm{MB}$ in flasks on a rotary shaker (200 r.p.m.) at $28{ }^{\circ} \mathrm{C}$ for 3 days. Chemotaxonomic data for strain JSM $078169^{\mathrm{T}}$ were consistent with its assignment to the genus Halomonas. The strain contained Q-9 $(96.6 \%)$ as the predominant respiratory quinone, with Q-7 (1.2\%), Q-8 $(1.4 \%)$ and Q-10 $(0.7 \%)$ present in minor amounts. The fatty acid profile of strain JSM $078169^{\mathrm{T}}$ was similar to those of the type strains of the four phylogenetically related Halomonas species (Table 2). The major fatty acids of strain JSM $078169^{\mathrm{T}}$ were $\mathrm{C}_{18: 1} \omega 7 c(48.9 \%), \mathrm{C}_{16: 0}(17.0 \%)$ and $\mathrm{C}_{12: 0} 3-\mathrm{OH}(10.7 \%)$.

Table 2. Fatty acid compositions of strain JSM $078169^{\top}$ and related Halomonas species

Strains: 1, JSM $078169^{\mathrm{T}}$ (H. zhanjiangensis sp. nov.); 2, H. variabilis DSM $3051^{\mathrm{T}} ; 3, H$. boliviensis DSM $15516^{\mathrm{T}}$; 4, H. neptunia DSM $15720^{\mathrm{T}} ; 5$, H. sulfidaeris DSM $15722^{\mathrm{T}}$. Data are percentages of the total fatty acids. Fatty acids that represented $<0.5 \%$ for all strains are omitted. -, Not detected.

\begin{tabular}{|lccccc|}
\hline Fatty acid & $\mathbf{1}$ & $\mathbf{2}$ & $\mathbf{3}$ & $\mathbf{4}$ & $\mathbf{5}$ \\
\hline $\mathrm{C}_{10: 0}$ 이 & 0.5 & 2.4 & 3.4 & 2.2 & 2.0 \\
$\mathrm{C}_{10: 0} 3-\mathrm{OH}$ & - & 2.1 & 0.1 & 0.1 & 0.3 \\
$\mathrm{C}_{12: 0}$ & 0.9 & 1.6 & 1.2 & 1.9 & 1.3 \\
$\mathrm{C}_{12: 0} 3-\mathrm{OH}$ & 10.7 & 12.6 & 8.5 & 11.1 & 15.0 \\
$\mathrm{C}_{14: 0}$ & 9.2 & 3.6 & 1.1 & 0.5 & 0.5 \\
iso- $_{16: 0}$ & 0.9 & 1.0 & - & - & - \\
$\mathrm{C}_{16: 1} \omega 6 c / \omega 7 c$ & 8.2 & 3.9 & 13.9 & 3.9 & 9.5 \\
$\mathrm{C}_{16: 0}$ & 17.0 & 13.1 & 20.7 & 20.1 & 8.3 \\
anteiso-C $17: 0$ & 0.5 & 0.8 & 0.1 & - & - \\
$\mathrm{C}_{17: 1} \omega 8 c$ & 0.5 & - & - & - & - \\
$\mathrm{C}_{17: 0}$ & 0.7 & 1.1 & 0.3 & 0.3 & 0.2 \\
$\mathrm{C}_{17: 0}$ cyclo & - & 7.5 & 10.7 & 13.0 & 0.3 \\
$\mathrm{C}_{18: 1} \omega 7 c$ & 48.9 & 36.1 & 26.7 & 29.8 & 59.2 \\
$\mathrm{C}_{19: 0}$ cyclo $\omega 8 c$ & - & 12.5 & 11.1 & 15.3 & 0.9 \\
\hline
\end{tabular}

The results of the phylogenetic analysis and chemotaxonomic studies supported the view that strain JSM $078169^{\mathrm{T}}$ should be assigned to the genus Halomonas. However, the yellow pigmentation and the absence of oxidase activity, as well as the ability to produce acids from D-fructose and sucrose, differentiated the novel isolate markedly from its phylogenetically related Halomonas species (Table 1). Strain JSM $078169^{\mathrm{T}}$ could also be distinguished from its closest phylogenetic neighbour $H$. variabilis by their discriminative fatty acid profiles, in which $\mathrm{C}_{17: 0}$ cyclo and $\mathrm{C}_{19: 0}$ cyclo $\omega 8 \mathrm{c}$ were not detected in the fatty acid pool of strain JSM $078169^{\mathrm{T}}$, whereas significant amounts of these two fatty acids were present in the type strain of $H$. variabilis (Table 2). Moreover, strain JSM $078169^{\mathrm{T}}$ could be clearly distinguished from its closest phylogenetic neighbour by some other discriminative taxonomic markers, such as its capacity of nitrate reduction and acid production from D-glucose, maltose and sucrose and the comparatively higher margin of the DNA G $+\mathrm{C}$ content $(\sim 5 \mathrm{~mol} \%$ ) between them (Table 1). Together with the low levels of DNA-DNA relatedness between strain JSM $078169^{\mathrm{T}}$ and the type strains of the phylogenetically related Halomonas species, the results of the polyphasic taxonomic study presented here allowed us to assign the isolate as representing a novel species, for which we propose the name Halomonas zhanjiangensis sp. nov.

\section{Description of Halomonas zhanjiangensis sp. nov.}

Halomonas zhanjiangensis (zhan.ji.ang.en'sis. N.L. fem. adj. zhanjiangensis pertaining to Zhanjiang, a city in China near where the sample was collected).

Cells are slightly halophilic, strictly aerobic, non-sporulating, catalase-positive, oxidase-negative, Gram-negative rods, approximately $0.7-1.4 \mu \mathrm{m}$ wide and $1.5-2.5 \mu \mathrm{m}$ long, occurring singly or as doublets and motile with peritrichous flagella. Accumulate poly- $\beta$-hydroxybutyrate, but do not produce exopolysaccharide. Colonies are yellow-pigmented, flat and non-translucent with glistening surfaces and circular/slightly irregular margins, $2-3 \mathrm{~mm}$ in diameter after incubation on MA at $28{ }^{\circ} \mathrm{C}$ for $3-5$ days. No diffusible pigments are produced. Growth occurs in 1$20 \%(\mathrm{w} / \mathrm{v})$ total salts (optimum, $3-5 \%$ ), at $\mathrm{pH} 6.0-10.5$ (optimum, $\mathrm{pH} 7.5$ ) and $4-40{ }^{\circ} \mathrm{C}$ (optimum, $25-30{ }^{\circ} \mathrm{C}$ ). No growth occurs in the absence of $\mathrm{NaCl}$ or with $\mathrm{NaCl}$ as the sole salt. Positive for nitrate reduction and oxidation of glucose, but negative for nitrite reduction, fermentation of glucose, phenylalanine deaminase and lysine and ornithine decarboxylases. Respiration on nitrate, nitrite and fumarate under anaerobic conditions is not observed. $\mathrm{H}_{2} \mathrm{~S}$ is not produced from L-cysteine. Indole production and methyl red and Voges-Proskauer tests are negative. Tween 60 is hydrolysed, but aesculin, casein, cellulose, DNA, gelatin, starch, Tweens 20, 40 and 80 and urea are not. Acids are produced from D-fructose, D-glucose, maltose, sucrose and trehalose, but not from L-arabinose, cellobiose, dulcitol, D-galactose, D-lactose, D-mannose, melezitose, melibiose, 
raffinose, L-rhamnose, D-ribose, D-salicin, starch, D-xylose, adonitol, glycerol, myo-inositol, D-mannitol or D-sorbitol. The following compounds are utilized as sole source of carbon and energy or sole source of carbon, nitrogen and energy: L-arabinose, D-fructose, D-glucose, maltose, acetate, butyrate, citrate, pyruvate, L-alanine, L-asparagine, Lglutamic acid, L-leucine, L-proline and L-serine; the following substances are not utilized: aesculin, cellobiose, dextrin, D-galactose, D-lactose, D-mannose, melezitose, melibiose, raffinose, L-rhamnose, D-ribose, D-salicin, starch, sucrose, trehalose, D-xylose, adonitol, D-arabitol, ethanol, glycerol, myo-inositol, D-mannitol, D-sorbitol, benzoate, caprylate, formate, fumarate, gluconate, hippurate, malate, malonate, propionate, succinate, L-arginine, Lcysteine, glycine, L-histidine, hydroxy-L-proline, L-isoleucine, L-methionine, L-threonine, L-tryptophan and L-valine. Constitutive enzymes expressed are acid phosphatase, alkaline phosphatase, leucine arylamidase, naphthol-ASBI-phosphohydrolase and valine arylamidase; $N$-acetyl- $\beta$ glucosaminidase, $\alpha$-chymotrypsin, cystine arylamidase, esterase (C4), esterase lipase (C8), $\alpha$-fucosidase, $\alpha$-galactosidase, $\beta$-galactosidase, $\alpha$-glucosidase, $\beta$-glucosidase, $\beta$ glucuronidase, lipase (C14), $\alpha$-mannosidase and trypsin are not observed (API ZYM). Susceptible to ( $\mu \mathrm{g}$ per disc): ampicillin (30), carbenicillin (30), gentamicin (10), nalidixic acid (20), polymixin B (30), rifampicin (5) and streptomycin (10), but not to chloramphenicol (30), kanamycin (30), lincomycin (2), nitrofurantoin (30), novobiocin (30), tetracycline (30) or tobramycin (10). Major fatty acids are $\mathrm{C}_{18: 1} \omega 7 c, \mathrm{C}_{16: 0}$ and $\mathrm{C}_{12: 0} 3-\mathrm{OH}$. Predominant respiratory quinone is Q-9. The DNA G + C content of the type strain is $55.8 \mathrm{~mol} \%$ (HPLC).

The type strain, JSM $078169^{\mathrm{T}}\left(=\right.$ CCTCC AB $208031^{\mathrm{T}}=$ DSM $21076^{\mathrm{T}}=$ KCTC $22279^{\mathrm{T}}$ ), was isolated from homogenates of a sea urchin (Hemicentrotus pulcherrimus) collected from a tidal flat of Naozhou Island in the South China Sea, near a southern city, Zhanjiang.

\section{Acknowledgements}

This work was supported by grants from the National Natural Science Foundation of China (NSFC) (30970007, 30860013), Jishou University (jsdxkyzz200811), National Basic Research Program of China (2010CB833800) and International Cooperation Research Program of Yunnan Province (2009AC017). We are grateful to $\mathrm{Mr}$ Yun Chen and Mr Huai-Dong Xiao for their excellent technical assitance.

\section{References}

Arahal, D. R., Vreeland, R. H., Litchfield, C. D., Mormile, M. R., Tindall, B. J., Oren, A., Bejar, V., Quesada, E. \& Ventosa, A. (2007). Recommended minimal standards for describing new taxa of the family Halomonadaceae. Int J Syst Evol Microbiol 57, 2436-2446.

Atlas, R. M. (1993). Handbook of Microbiological Media. Edited by L. C. Parks. Boca Raton, FL: CRC Press.

Ben Ali Gam, Z., Abdelkafi, S., Casalot, L., Tholozan, J. L., Oueslati, R. \& Labat, M. (2007). Modicisalibacter tunisiensis gen. nov., sp. nov., an aerobic, slightly halophilic bacterium isolated from an oilfieldwater injection sample, and emended description of the family Halomonadaceae Franzmann et al. 1989 emend Dobson and Franzmann 1996 emend. Ntougias et al. 2007. Int J Syst Evol Microbiol 57, 2307-2313.

Chen, Y.-G., Cui, X.-L., Pukall, R., Li, H.-M., Yang, Y.-L., Xu, L.-H., Wen, M.-L., Peng, Q. \& Jiang, C.-L. (2007). Salinicoccus kunmingensis sp. nov., a moderately halophilic bacterium isolated from a salt mine in Yunnan, south-west China. Int J Syst Evol Microbiol 57, 2327-2332.

Chen, Y.-G., Zhang, Y.-Q., Shi, J.-X., Xiao, H.-D., Tang, S.-K., Liu, Z.-X., Huang, K., Cui, X.-L. \& Li, W.-J. (2009a). Jeotgalicoccus marinus sp. nov., a marine bacterium isolated from a sea urchin. Int J Syst Evol Microbiol 59, 1625-1629.

Chen, Y.-G., Zhang, Y.-Q., Xiao, H.-D., Liu, Z.-X., Yi, L.-B., Shi, J.-X., Zhi, X.-Y., Cui, X.-L. \& Li, W.-J. (2009b). Pontibacillus halophilus sp. nov., a moderately halophilic bacterium isolated from a sea urchin. Int J Syst Evol Microbiol 59, 1635-1639.

Chun, J., Lee, J.-H., Jung, Y., Kim, M., Kim, S., Kim, B. K. \& Lim, Y. W. (2007). EzTaxon: a web-based tool for the identification of prokaryotes based on $16 \mathrm{~S}$ ribosomal RNA gene sequences. Int J Syst Evol Microbiol 57, 2259-2261.

Cowan, S. T. \& Steel, K. J. (1965). Manual for the Identification of Medical Bacteria. London: Cambridge University Press.

Cui, X.-L., Mao, P.-H., Zeng, M., Li, W.-J., Zhang, L.-P., Xu, L.-H. \& Jiang, C.-L. (2001). Streptomonospora salina gen. nov., sp. nov., a new member of the family Nocardiopsaceae. Int J Syst Evol Microbiol 51, 357-363.

Dobson, S. J. \& Franzmann, P. D. (1996). Unification of the genera Deleya (Baumann et al. 1983), Halomonas (Vreeland et al. 1980), and Halovibrio (Fendrich 1988) and the species Paracoccus halodenitrificans (Robinson and Gibbons 1952) into a single genus, Halomonas, and placement of the genus Zymobacter in the family Halomonadaceae. Int J Syst Bacteriol 46, 550-558.

Ezaki, T., Hashimoto, Y. \& Yabuuchi, E. (1989). Fluorometric deoxyribonucleic acid-deoxyribonucleic acid hybridization in microdilution wells as an alternative to membrane filter hybridization in which radioisotopes are used to determine genetic relatedness among bacterial strains. Int J Syst Bacteriol 39, 224-229.

Felsenstein, J. (1985). Confidence limits on phylogenies: an approach using the bootstrap. Evolution 39, 783-791.

Felsenstein, J. (1997). An alternative least-squares approach to inferring phylogenies from pairwise distances. Syst Biol 46, 101-111.

Fendrich, C. (1988). Halovibrio variabilis gen. nov. sp. nov., Pseudomonas halophila sp. nov. and a new halophilic aerobic coccoid Eubacterium from Great Salt Lake, Utah, USA. Syst Appl Microbiol 11, 36-43.

Franzmann, P. D., Wehmeyer, U. \& Stackebrandt, E. (1988). Halomonadaceae fam. nov., a new family of the class Proteobacteria to accommodate the genera Halomonas and Deleya. Syst Appl Microbiol 11, 16-19.

Gregersen, T. (1978). Rapid method for distinction of Gram-negative from Gram-positive bacteria. Eur J Appl Microbiol Biotechnol 5, 123-127.

Groth, I., Schumann, P., Weiss, N., Martin, K. \& Rainey, F. A. (1996). Agrococcus jenensis gen. nov., sp. nov., a new genus of actinomycetes with diaminobutyric acid in the cell wall. Int J Syst Bacteriol 46, 234239.

Hopwood, D. A., Bibb, M. J., Chater, K. F., Kieser, T., Bruton, C. J., Kieser, H. M., Lydiate, D. J., Smith, C. P. \& Ward, J. M. (1985). Preparation of chromosomal, plasmid and phage DNA. In Genetic Manipulation of Streptomyces: a Laboratory Manual, pp. 79-80. Norwich, UK: John Innes Foundation. 
Kaye, J. Z., Márquez, M. C., Ventosa, A. \& Baross, J. A. (2004). Halomonas neptunia sp. nov., Halomonas sulfidaeris sp. nov., Halomonas axialensis sp. nov. and Halomonas hydrothermalis sp. nov., halophilic bacteria isolated from deep-sea hydrothermal-vent environments. Int J Syst Evol Microbiol 54, 499-511.

Kimura, M. (1980). A simple method for estimating evolutionary rates of base substitutions through comparative studies of nucleotide sequences. J Mol Evol 16, 111-120.

Kluge, A. G. \& Farris, J. S. (1969). Quantitative phyletics and the evolution of anurans. Syst Zool 18, 1-32.

Li, H.-B., Zhang, L.-P. \& Chen, S.-F. (2008). Halomonas korlensis sp. nov., a moderately halophilic, denitrifying bacterium isolated from saline and alkaline soil. Int J Syst Evol Microbiol 58, 2582-2588.

Mata, J. A., Martínez-Cánovas, J., Quesada, E. \& Bèjar, V. (2002). A detailed phenotypic characterization of the type strains of Halomonas species. Syst Appl Microbiol 25, 360-375.

Mesbah, M., Premachandran, U. \& Whitman, W. B. (1989). Precise measurement of the $\mathrm{G}+\mathrm{C}$ content of deoxyribonucleic acid by highperformance liquid chromatography. Int J Syst Bacteriol 39, 159-167.

Ntougias, S., Zervakis, G. I. \& Fasseas, C. (2007). Halotalea alkalilenta gen. nov., sp. nov., a novel osmotolerant and alkalitolerant bacterium from alkaline olive mill wastes, and emended description of the family Halomonadaceae Franzmann et al. 1989, emend. Dobson and Franzmann 1996. Int J Syst Evol Microbiol 57, 1975-1983.

Quillaguamán, J., Hatti-Kaul, R., Mattiasson, B., Alvarez, M. T. \& Delgado, O. (2004). Halomonas boliviensis sp. nov., an alkalitolerant, moderate halophile isolated from soil around a Bolivian hypersaline lake. Int J Syst Evol Microbiol 54, 721-725.

Romanenko, L. A., Schumann, P., Rohde, M., Mikhailov, V. V. \& Stackebrandt, E. (2002). Halomonas halocynthiae sp. nov., isolated from the marine ascidian Halocynthia aurantium. Int J Syst Evol Microbiol 52, 1767-1772.

Saitou, N. \& Nei, M. (1987). The neighbor-joining method: a new method for reconstructing phylogenetic trees. Mol Biol Evol 4, 406-425.

Sasser, M. (1990). Identification of bacteria by gas chromatography of cellular fatty acids, MIDI Technical Note 101. Newark, DE: MIDI Inc.

Smibert, R. M. \& Krieg, N. R. (1994). Phenotypic characterization. In Methods for General and Molecular Bacteriology, pp. 607-654. Edited by P. Gerhardt, R. G. E. Murray, W. A. Wood \& N. R. Krieg. Washington, DC: American Society for Microbiology.
Stackebrandt, E. \& Goebel, B. M. (1994). Taxonomic note: a place for DNA-DNA reassociation and $16 \mathrm{~S}$ rRNA sequence analysis in the present species definition in bacteriology. Int J Syst Bacteriol 44, 846849.

Tamura, K., Dudley, J., Nei, M. \& Kumar, S. (2007). MEGA4: molecular evolutionary genetic analysis (MEGA) software version 4.0. Mol Biol Evol 24, 1596-1599.

Thompson, J. D., Gibson, T. J., Plewniak, F., Jeanmougin, F. \& Higgins, D. G. (1997). The CLUSTAL_X windows interface: flexible strategies for multiple sequence alignment aided by quality analysis tools. Nucleic Acids Res 25, 4876-4882.

Ventosa, A., Quesada, E., Rodriguez-Valera, F., Ruiz-Berraquero, F. \& Ramos-Cormenzana, A. (1982). Numerical taxonomy of moderately halophilic Gram-negative rods. J Gen Microbiol 128, 1959-1968.

Vreeland, R. H., Litchfield, C. D., Martin, E. L. \& Elliot, E. (1980). Halomonas elongata, a new genus and species of extremely salttolerant bacteria. Int J Syst Bacteriol 30, 485-495.

Wang, Y., Wu, Y.-H., Wang, C.-S., Xu, X.-W., Oren, A., Zhu, X.-F. \& Wu, M. (2008). Halomonas salifodinae sp. nov., a halophilic bacterium isolated from a salt mine in China. Int J Syst Evol Microbiol 58, 28552858.

Wayne, L. G., Brenner, D. J., Colwell, R. R., Grimont, P. A. D., Kandler, O., Krichevsky, M. I., Moore, L. H., Moore, W. E. C., Murray, R. G. E. \& other authors (1987). International Committee on Systematic Bacteriology. Report of the ad hoc committee on reconciliation of approaches to bacterial systematics. Int J Syst Bacteriol 37, 463-464.

Wu, G., Wu, X.-Q., Wang, Y.-N., Chi, C.-Q., Tang, Y.-O., Kida, K., Wu, X.-L. \& Luan, Z.-K. (2008). Halomonas daqingensis sp. nov., a moderately halophilic bacterium isolated from an oilfield soil. Int $J$ Syst Evol Microbiol 58, 2859-2865.

Xiao, H.-D., Chen, Y.-G., Liu, Z.-X., Huang, K., Li, W.-J., Cui, X.-L., Zhang, L. \& Yi, L.-B. (2009). Phylogenetic diversity of cultivable bacteria associated with a sea anemone from coast of the Naozhou Island in Zhanjiang, China. Wei Sheng Wu Xue Bao 49, 246-250 (in Chinese).

Xu, X.-W., Wu, Y.-H., Zhou, Z., Wang, C.-S., Zhou, Y.-G., Zhang, H.-B., Wang, Y. \& Wu, M. (2007). Halomonas saccharevitans sp. nov., Halomonas arcis sp. nov. and Halomonas subterranea sp. nov., halophilic bacteria isolated from hypersaline environments of China. Int J Syst Bacteriol 57, 1619-1624. 